\title{
AKIBAT HUKUM VERIFIKASI DAN VALIDASI BEA PEROLEHAN HAK ATAS TANAH DAN BANGUNAN \\ OLEH DINAS PENGELOLAAN PENDAPATAN KEUANGAN DAN ASET DAERAH TERHADAP AKTA PPAT DI KABUPATEN TEGAL
}

Junaidi

Anis Mashdurohatun

\begin{abstract}
ABSTRAK
Penelitian dengan judul "Akibat Hukum Verifikasi Dan Validasi Bea Perolehan Hak Atas Tanah Dan Bangunan Oleh Dinas Pengelolaan Pendapatan Keuangan Dan Aset Daerah Terhadap Akta PPAT di Kabupaten Tegal" dengan menggunakan pendekatan metode yuridis empiris, dalam pengumpulan data yang ada dilapangan dengan wawancara kepada para pihak yang terkait dengan masalah yang di teliti kemudian dikaji dengan sumber hukum berupa peraturan perundang-undangan, kaidah-kaidah hukum maupun teori ilmu hukum.

Penelitian ini menghasilkan pada pokoknya : Pelaksanaan verifikasi dan validasi Bea Perolehan Hak Atas Tanah Dan Bangunan oleh Dinas Pengelolaan Pendapatan Keuangan Dan Aset Daerah Terhadap Akta PPAT Di Kabupaten Tegal di atur dalam Peraturan Bupati Tegal Nomor 32 tahun 2012 Tentang Tentang Bea Perolehan Hak Atas Tanah Dan Bangunan yaitu pasal 31 sampai dengan pasal 35. Dalam penentuan besaran BPHTB mendasarkan pada nilai terbesar antara nilai jual beli sebagaimana akta jual beli dan nilai NJOP dan nilai transaksi/nilai pasar yang telah di tentukan oleh Dinas Pengelolaan Pendapatan Keuangan Dan Aset Daerah. Akibat hukum dari Sistem verifikasi dan validasi pembayaran BPHTB yang diatur di dalam Peraturan Bupati Nomor 32 tahun 2012 sudah menghilangkan prinsip sistem Self Assessment karena Wajib Pajak tidak dapat lagi menghitung dan membayarkan sendiri utang pajaknya. Sehingga Peraturan Peraturan Bupati Nomor 32 tahun 2012 Tentang Tentang Bea Perolehan Hak Atas Tanah Dan Bangunan tersebut tidak sesuai dengan aturan yang terdapat dalam Peraturan Pemerintah Nomor 91 Tahun 2010 tentang Jenis Pajak Darah yang dipungut berdasarkan penetapan kepala daerah atau dibayar sendiri oleh wajib pajak, sehingga dapat dibatalkan demi hukum. Akta PPAT selama memenuhi syarat sahnya perjanjian sebagaimana dalam Pasal 1320 KUHPerdata, serta di buat oleh pejabat yang berwenang dengan berdasarkan undang-undang sebagaimana Pasal 1868 KUH Perdata mempunyai kekuatan hukum mengikat sebagaimana kekuatan hukum akta ontentik, meskipun tidak bisa dilaksanakan ketika dalam Verifikasi Dan Validasi Bea Perolehan Hak Atas Tanah Dan Bangunan oleh Dinas Pengelolaan Pendapatan Keuangan Dan Aset Daerah.
\end{abstract}

Kata kunci : Akibat Hukum, Verifikasi Dan Validasi, Bea Perolehan Hak Atas Tanah Dan Bangunan

\section{A. PENDAHULUAN}

\section{Latar Belakang}

Pajak Bea Perolehan Hak Atas Tanah dan Bangunan (BPHTB), sebenarnya bukanlah hal yang baru dalam bidang perpajakan yang dipungut oleh pemerintah. Dasar hukum pemungutan atas pajak Bea Perolehan Hak Atas Tanah dan Bangunan (BPHTB) adalah berlakunya Undang-undang Nomor 21 Tahun 1997 tentang Bea Perolehan Hak Atas Tanah dan Bangunan (BPHTB) yang dikeluarkan pada tanggal 29 Mei 1997. Dalam memori penjelasan Undang-undang Nomor 21 Tahun 1997 tentang Bea Perolehan Hak Atas Tanah dan Bangunan (BPHTB) disebutkan, bahwa tanah sebagai bagian dari bumi yang merupakan karunia Tuhan Yang Maha Esa serta memiliki fungsi sosial, disamping memenuhi kebutuhan dasar untuk papan dan lahan usaha, juga merupakan alat investasi yang sangat menguntungkan. Di samping itu bagi mereka yang memperoleh hak atas tanah dan bangunan, wajib menyetorkan kepada negara melalui pembayaran pajak, dalam hal ini Bea Perolehan Hak Atas Tanah dan Bangunan (BPHTB).

Pengalihan pengelolaan Bea Perolehan Hak atas Tanah dan Bangunan (BPHTB) dari Pemerintah Pusat kepada Pemerintah Daerah merupakan suatu bentuk tindak lanjut kebijakan otonomi daerah dan desentralisasi fiskal. Bentuk kebijakan tersebut dituangkan ke dalam undang-undang Nomor 28 Tahun 2009 tentang Pajak Daerah dan Retribusi Daerah. ${ }^{2}$

Pemungutan BPHTB adalah salah satu bagian yang sangat penting dalam proses peralihan hak ( balik nama ) atas tanah dan bangunan di Indonesia, karena Notaris dan Pejabat Pembuat Akta Tanah ( PPAT ) dilarang untuk menandatangani akta peralihan hak sebelum wajib pajak melunasi BPHTB sebagaimana mestinya. ${ }^{3}$

1 Penjelasan Undang-undang Nomor 21 Tahun 1997 tentang Bea Perolehan Hak Atas Tanah dan Bangunan (BPHTB).

2 http://www.pajak.go.id/content/pengalihan-pbbperdesaan-dan-perkotaan di akses 20 desember 2016

3 Marihot Paha Siahaan, 2010, Kompilasi Peraturan Di Bidang BPHTB, Panduan Dalam Penyusunan 
Peraturan Pemerintah Nomor 91 Tahun 2010 Tentang Jenis Pajak Daerah Yang Dipungut berdasarkan Penetapan Kepala Daerah atau Dibayar Sendiri Oleh Wajib Pajak adalah peraturan pelaksanaan atas Undang-undang Nomor 28 Tahun 2009 tentang Pajak Daerah dan Retribusi Daerah. ${ }^{4}$ Dalam peraturan ini ditetapkan bahwa pemungutan BPHTB dilakukan berdasarkan prinsip menghitung dan membayar sendiri pajak terutang (Self Assessment System).

Self Assessment System adalah suatu sistem perpajakan dalam mana inisiatif untuk memenuhi kewajiban perpajakan berada di Wajib Pajak. ${ }^{5}$ Sistem pemungutan pajak dengan Self Assessment System memberikan kewenangan kepada wajib pajak untuk menghitung, menyetor dan melaporkan sendiri pajak terutang sedangkan fiskus hanya mengawasi saja. ${ }^{6}$

Persoalan yang sering timbul adalah PBHTB yang di tentukan oleh DPPKAD kabupaten Tegal lebih besar dari ketentuan Undang-Undang Nomor 28 Tahun 2009 yang mana DPPKAD dalam menentukan besaran PBHTB selain dengan perhitungan menurut ketentuan presentasi (\%) berdasarkan Undang-Undang Nomor 28 Tahun 2009 juga mendasarkan nilai tanah dan bangunan berdasarkan zonasi yang telah di tentukan yang mendasarkan pada Peraturan Bupati Tegal nomor 32 Tahun 2012 tentang Bea Perolehan Hak Atas Tanah Dan Bangunan (PBHTB) yang mana dalam penentuan harga tanah berdasarkan zonasi yang dapat akses dengan sistem E- PBHTB Kabupaten Tegal. Hal yang demikian tidak sesuai ketentuan Undang-Undang Nomor 28 Tahun 2009 yang mana PBHTB di hitung berdasarkan presentasi (\%) jual beli tanah dan bangunan yang terdapat dalam akta.

Bertitik tolak dari latar belakang tersebut di atas, maka dilakukan suatu penelitian dan menyusunnya dalam artikel untuk jurnal yang berjudul "Akibat Hukum Verifikasi Dan Validasi Bea Perolehan Hak Atas Tanah Dan Bangunan Oleh Dinas Pengelolaan Pendapatan Keuangan Dan Aset Daerah Terhadap Akta PPAT Di Kabupaten Tegal”

\section{Rumusan Masalah}

Adapun rumusan masalah dalam penelitian ini sebagai berikut :

1. Bagaimana pelaksanaan verifikasi dan validasi Bea Perolehan Hak Atas Tanah Dan Bangunan oleh Dinas Pengelolaan Pendapatan Keuangan Dan Aset Daerah Terhadap Akta PPAT Di Kabupaten Tegal saat ini ?

Aturan Pelaksanaan Peraturan Daerah Tentang BPHTB, Graha Ilmu, Yogyakarta, h. 7.

4 Pasal 98 Undang-undang Nomor 28 Tahun 2009 Tentang Pajak Daerah dan Retribusi Daerah.

5 Safri Nurmanu, op.cit. h. 110

6 Soemitro Rochmat, dalam Mardiasmo Mardiasmo, 2002, Perpajakan, Edisi Revisi, Penerbit Andi, Yogyakarta. h.5.
2. Apa sajakah yang menjadi hambatan-hambatan serta solusi dalam pelaksanaan verifikasi dan validasi Bea Perolehan Hak Atas Tanah dan Bangunan oleh Dinas Pengelolaan Pendapatan Keuangan Dan Aset Daerah Terhadap Akta PPAT Di Kabupaten Tegal?

3. Bagaimana akibat hukum Verifikasi Dan Validasi Bea Perolehan Hak Atas Tanah dan Bangunan oleh Dinas Pengelolaan Pendapatan Keuangan Dan Aset Daerah Terhadap Akta PPAT Di Kabupaten Tegal?

\section{B. PEMBAHASAN}

1. Pelaksanaan Verifikasi Dan Validasi Bea Perolehan Hak Atas Tanah Dan Bangunan oleh Dinas Pengelolaan Pendapatan Keuangan Dan Aset Daerah Terhadap Akta PPAT Di Kabupaten Tegal

Penyetoran pajak Bea Perolehan Hak atas Tanah dan Bangunan (BPHTB) harus dilakukan verifikasi terhadap kelengkapan dokumen dan kebenaran data terkait objek pajak yang tercantum dalam Surat Setoran Pajak Daerah BPHTB sebelum wajib pajak melakukan pembayaran BPHTB terutang oleh Dinas Pengelolaan Pendapatan Keuangan Dan Aset Daerah.

Bahwa dalam pelaksanaan verifikasi DPPKAD melakukan penelitian SSPD yang telah dibayar yang di sampaikan oleh wajib pajak atau kuasanya untuk keperluan penelitian, dalam verifikasi ini Dinas telah menentukan besaran nilai transaksi/nilai pasar sendiri sehingga apabila dalam penelitian di temukan dalam penelitian SSPD ternyata nilai transaksi kurang dari nilai yang di tentukan oleh Dinas maka berkas SSPD akan di kembalikan kepada wajib pajak/ kuasanya untuk di perbaiki sebagaimana yang telah di tentukan oleh Dinas.

Penentuan besaran trasnsaksi/nilai pasar ini sebagai dasar besaran BPHTB yang mana penentuan besaran ini tidak berdasarkan pada nilai NJOP akan tetapi berdasarkan analisa Dinas dengan mengambil rata-rata harga pasaran yang ada dalam wilayah objek pajak $^{7}$ Dengan demikian wajib pajak harus mengikuti besaran pajak yang di bayar yang telah di tetapkan oleh dinas, yang mana wajib pajak tidak mengitung pajak sendiri sebagaimana asas self assessment.

Selain itu apabila besaran NJOP lebih tinggi dari Penentuan besaran trasnsaksi/nilai pasar dan nilai dalam akta jual beli maka yang di gunakan besaran BPHTB adalah nilai NJOP, sehingga wajib pajak tidak di beri kewenangan menghitung pajak sendiri sebagaimana asas self assessment.

Hal ini akan menjadi persoalan tersendiri apabila harga transaksi yang lakukan oleh wajib pajak

7 Hasil wawancara dengan Notaris/PPAT Prasetyaningsih, SH jalan Ahmad Yani Nomor 19, Procot Slawi pada tanggal 20 Februari 2017 
kurang dari besaran trasnsaksi/nilai pasar ataupun NJOP. hal ini sebagaimana contoh kasus.

Bahwa telah terjadi jual beli sebidang tanah antara Najikha, Najibah, Siti Muhlisoh, Faridah, Labibah, dengan Teguh Purwadi sebagaimana akta jual beli nomor 105/2014 yang di buat PPAT HM. Marsudi, yang mana nilai transaksi jual beli tersebut adalah Rp. 55.000.000, - (lima puluh lima juta rupiah), NJOP Rp. 35.046.000.- harga transaksi/nilai pasar Rp.75.000.000,

Atas transaksi jual beli Teguh Purwadi melakukan pembayaran BPHTB pada tahun 2016, dalam pembayaran BPHTB Teguh Purwadi tidak menghitung besaran BPHTB dengan mendasarkan nilai transaksi jual beli yang tercantum dalam akta sebagaimana asas self assessment, ataupun dari nilai NJOP akan tetapi Teguh Purwadi harus mendasarkan berasan harga transaksi/nilai pasar atas obyek tersebut yang telah di tentukan oleh Dinas yaitu sebesar Rp.75.000.000,- (tujuh puluh lima juta rupiah). dengan BPHTB yang harus di bayar sebesar Rp. 750.000,(Tujuh ratus lima puluh ribu rupiah )

2. Hambatan-hambatan dan Solusi dalam verifikasi dan validasi Bea Perolehan Hak Atas Tanah dan Bangunan oleh Dinas Pengelolaan Pendapatan Keuangan Dan Aset Daerah Terhadap Akta PPAT Di Kabupaten Tegal.

Hambatan-Hambatan verifikasi dan validasi

Bea Perolehan Hak Atas Tanah dan Bangunan oleh Dinas Pengelolaan Pendapatan Keuangan Dan Aset Daerah Terhadap Akta PPAT Di Kabupaten Tegal terkait isi Akta.

a. Nilai jual beli yang tercantum di akta jual beli yang di buat oleh PPAT di bawah nilai transaksi/nilai pasar akan tetapi di atas nilai NJOP yang telah di tetapkan Dinas Pengelolaan Pendapatan Keuangan Dan Aset Daerah

b. Nilai jual beli yang tercantum di akta jual beli yang di buat oleh PPAT di bawah NJOP akan di atas nilai transaksi/nilai yang telah di tetapkan Dinas Pengelolaan Pendapatan Keuangan Dan Aset Daerah

Dua hambatan tersebut di atas merupakan hambatan dalam pembayaran BPHTB karena sebagaimana yang penulis bahas di atas dalam pelaksanaan pembayaran BPHTB tidak semata-mata mendasarkan pada nilai transaksi jual beli melainkan bisa mendasarkan pada nilai NJOP atau nilai transaksi/nilai pasar di lihat nilai mana yang lebih besar.

Sehingga dalam mengatasi solusi tersebut adalah sebagai berikut, dalam hambatan pertama solusinya adalah menrenvoi/merubah isi akta menyesuaikan nilai transaksi/nilai pasar yang telah di tetap oleh DPPKAD sehingga besaran BPHTB yang harus di bayar wajib pajak menyesuaikan nilai transaksi/nilai pasar. ${ }^{8}$

Solusi hambatan yang kedua yaitu tidak merubah akta melainkan pembayaran BPHTB tidak mendasarkan pada akta jual beli melainkan mendasarkan pada NJOP Dinas Pengelolaan Pendapatan Keuangan Dan Aset Daerah. ${ }^{9}$

Hal yang demikian karena verifikasi dan validasi BPHTB oleh DPPKAD kabupaten Tegal mendasarkan pada nilai yang lebih tinggi yang sebelumnya telah di tentukan sebelumnya.

3. Akibat Hukum Verifikasi Dan Validasi Bea Perolehan Hak Atas Tanah dan Bangunan Oleh Dinas Pengelolaan Pendapatan Keuangan Dan Aset Daerah Terhadap Akta PPAT Di Kabupaten Tegal.

Bahwa dengan pelaksanaan Verifikasi Dan Validasi Bea Perolehan Hak Atas Tanah dan Bangunan oleh DPPKAD Terhadap Akta PPAT Di Kabupaten Tegal berdasarkan Peraturan Peraturan Bupati Nomor 32 tahun 2012 Tentang Tentang Bea Perolehan Hak Atas Tanah Dan Bangunan tersebut tidak sesuai dengan aturan yang terdapat dalam Peraturan Pemerintah Nomor 91 tahun 2010 sehingga dalam pelaksanaan Verifikasi Dan Validasi BPHTB oleh DPPKAD Terhadap Akta PPAT Di Kabupaten Tegal dapat dibatalkan demi hukum hal ini sesuai asas hukum lex supperiori derogat lex inferiori (hukum yang ada di bawah tidak boleh bertentangan dengan hukum yang di atasnya). Berdasarkan teori ini, maka peraturan perundang undangan yang berada di bawah, jika bertentangan dengan peraturan perundang undangan yang ada di atasnya, ia dapat dibatalkan demi hukum.

Akhibat Hukum Akta PPAT Terhadap Verifikasi Dan Validasi Bea Perolehan Hak Atas Tanah Dan Bangunan oleh Dinas Pengelolaan Pendapatan Keuangan Dan Aset Daerah adalah sah maka selama Akta PPAT memenuhi syarat subjektif dan objektif sahnya perjanjian sebagaimana dalam Pasal 1320 KUHPerdata, serta di buat oleh pejabat yang berwenang dengan berdasarkan undang-undang sebagaimana Pasal 1868 KUH Perdata.

\section{PENUTUP \\ Kesimpulan}

Dari uraian di atas terkait penulisan penelitian dengan judul"Akibat hukum Verifikasi dan validasi bea perolehan hak atas tanah dan bangunan Oleh Dinas Pengelolaan Pendapatan Keuangan Dan Aset Daerah Terhadap Akta PPAT Di Kabupaten Tegal" dapat penulis simpulkan sebagai berikut:

\footnotetext{
8 Hasil wawancara dengan Notaris/PPAT Prasetyaningsih, SH jalan Ahmad Yani Nomor 19, Procot Slawi pada tanggal 21 Februari 2017. 9 ibid
} 
1. Akibat hukum dari Sistem verifikasi dan validasi pembayaran BPHTB yang diatur di dalam Peraturan Bupati Nomor 32 tahun 2012 sudah menghilangkan prinsip sistem Self Assessment karena Wajib Pajak tidak dapat lagi menghitung dan membayarkan sendiri utang pajaknya. Sehingga Peraturan Peraturan Bupati Nomor 32 tahun 2012 Tentang Tentang Bea Perolehan Hak Atas Tanah Dan Bangunan tersebut tidak sesuai dengan aturan yang terdapat dalam Peraturan Pemerintah Nomor 91 Tahun 2010 tentang Jenis Pajak Darah yang Dipungut Berdasarkan Penetapan Kepala Daerah atau dibayar Sendiri oleh Wajib Pajak, sehingga dapat dibatalkan demi hukum.

2. Akta PPAT selama memenuhi syarat sahnya perjanjian sebagaimana dalam Pasal 1320 KUHPerdata, serta di buat oleh pejabat yang berwenang dengan berdasarkan undang-undang sebagaimana Pasal 1868 KUH Perdata mempunyai kekuatan hukum mengikat sebagaimana kekuatan hukum akta ontentik, meskipun tidak bisa dilaksanakan ketika dalam Verifikasi Dan Validasi Bea Perolehan Hak Atas Tanah Dan Bangunan oleh Dinas Pengelolaan Pendapatan Keuangan Dan Aset Daerah.

\section{DAFTAR PUSTAKA}

Marihot Paha Siahaan, 2005, Bea Perolehan Hak Atas Tanah Dan Bangunan Teori Dan Praktek, Edisi I ,Cet. I, RajaGrafindo Persada, Jakarta.

Marihot Paha Siahaan, 2010, Kompilasi Peraturan Di Bidang BPHTB, Panduan Dalam Penyusunan Aturan Pelaksanaan Peraturan Daerah Tentang BPHTB, Graha Ilmu, Yogyakarta.
Safri Nurmanu, 2003, Pengantar Perpajakan, Yayasan Obor Indonesia, Jakarta.

Mardiasmo Mardiasmo, 2002, Perpajakan, Edisi Revisi, Penerbit Andi, Yogyakarta.

Undang-Undang Nomor 21 Tahun 1997 tentang Bea Perolehan Hak Atas Tanah dan Bangunan (BPHTB).

Undang-undang Nomor 20 Tahun 2000 tentang Perubahan atas Undang-undang Nomor 21 Tahun 1997 tentang Bea Perolehan Hak Atas Tanah dan Bangunan.

Peraturan Pemerintah Nomor 37 Tahun 1998 tentang Peraturan Jabatan Pejabat Pembuat Akta Tanah.

Peraturan Bupati Nomor 32 tahun 2012 Tentang Tentang Bea Perolehan Hak Atas Tanah Dan Bangunan;

Wawancara dengan Budi Sukamto pegawai Badan Pengelolaan Pendapatan Daerah kabupaten Tegal.

Wawancara dengan Notaris/PPAT Lilis Kristinawati, SH., M.kn Alamat Jalan Raya Bumi Harja No. 61 Tarub Kabupaten Tegal.

Wawancara dengan Notaris/PPAT Prasetyaningsih, SH jalan Ahmad Yani Nomor 19, Procot Slawi .

http://www.pajak.go.id/content/pengalihan-pbbperdesaan-dan-perkotaan di akses 20 desember 2016 